\title{
Toxin production by Burkholderia pseudomallei strains and correlation with severity of melioidosis
}

\author{
ANTJE HAASE, JULIA JANZEN, SIOBHAN BARRETT and B. CURRIE* \\ Menzies School of Health Research, PO Box 41096, Casuarina, NT 0811 and *Royal Darwin Hospital, \\ Rocklands Drive, Tiwi NT 0810, Australia
}

\begin{abstract}
An exotoxin lethal to cells in culture (cytolethal toxin, CLT) was identified in culture filtrates of Burkholderia pseudomallei, the causative organism of melioidosis. CLT could pass through a 10-kDa cut-off ultrafilter and its properties suggest that it is a peptide. Isolates from soil, animals and man showed differential cytolethality in vitro. The isolates were divided into low, medium and high CLT producers with soil isolates being low producers and isolates from patients with melioidosis encephalitis being high producers. CLT levels are subject to regulation, as a strain isolated from an infected goat was one of the highest producers whereas the same strain isolated from soil was a low producer. In addition to CLT, all isolates produced a protein with cell-elongating activity which was also present in culture filtrates.
\end{abstract}

\section{Introduction}

Melioidosis is a potentially fatal disease caused by a bacterium of the soil, Burkholderia (formerly Pseudomonas) pseudomallei. The disease is endemic in Southeast Asia and Northern Australia and incidences correlate with rainfall. Infection occurs through a wound or by inhalation and possibly by ingestion, and can disseminate causing pneumonia, septicaemia and multiple abscesses in all organs including the brain. The commonest clinical manifestation is pneumonia and in severe cases patients die within $48 \mathrm{~h}$ of onset of symptoms. People with underlying risk factors such as diabetes, high alcohol intake and renal disease are much more likely to manifest severe illness than others [1-4]. Sometimes the disease can remain latent for up to 26 years [5], the bacteria presumably surviving within macrophages. Relapses occur if the organism is not completely cleared after the first episode of the illness and when antibiotic resistance is acquired during treatment $[6,7]$.

In Northern Australia, a form of melioidosis brainstem encephalitis has been observed. Since the original description of seven cases, there have been five further cases at the Royal Darwin Hospital (Currie, unpublished data) [8] and cases elsewhere in Australia and overseas. It is not clear if all strains of $B$.

Received 27 June 1996; accepted 5 Nov. 1996.

Corresponding author: Dr A. Haase. pseudomallei have the potential to cause this manifestation or if it is due to a specific variant strain.

It is believed that exotoxins are responsible for the rapid onset of the disease and the dramatic course of septicaemic melioidosis. Two toxic activities have been found in culture filtrates of $B$. pseudomallei: one is lethal to mice and the other is dermonecrotic causing haemorrhage at the site of injection $[9,10]$. Strains also show proteolytic activity and a $35-\mathrm{kDa}$ protease has been purified and characterised [11]. A $31-\mathrm{kDa}$ protein with cytotoxic activity has also been isolated from culture filtrates $[12,13]$. This paper describes the partial purification and biological characterisation of an exotoxin of $B$. pseudomallei that is active in very small amounts and appears to be a cytolethal peptide.

\section{Materials and methods}

\section{Bacterial isolates}

Isolates of $B$. pseudomallei from man were from clinical cases of melioidosis at the Royal Darwin Hospital as grown for diagnostic purposes. Isolates from animals were kindly provided by the Department of Primary Industry and Fisheries in Darwin. Isolates from soil were from samples collected at various places in the Northern Territory of Australia. Soil was cultured in Ashdown's medium for 7 days at $37^{\circ} \mathrm{C}$ in stationary cultures and streaked out on Ashdown's plates and blood agar plates for purification. Identifica- 
tion of the organism was performed with API tests (bioMérieux).

\section{Toxin preparations}

Bacteria were grown for 7 days in $20 \mathrm{ml}$ of Todd Hewitt Broth (THB) medium or M9 medium (for toxin preparation) at $37^{\circ} \mathrm{C}$ without agitation. The cultures were centrifuged for $1 \mathrm{~h}$ at $4000 \mathrm{~g}$ and the supernate was filtered through a $0.22-\mu \mathrm{m}$ pore filter sterilising unit.

After ultrafiltration of the filtered supernate in an ultrafiltration unit (Amicon) fitted with a $10-\mathrm{kDa}$ cutoff membrane, cytolethal toxin (CLT) was isolated from the lower chamber and further purified on a Sephadex G25 column with $50 \mathrm{mM} \mathrm{NaCl}, 20 \mathrm{mM}$ Tris$\mathrm{HCl}, \mathrm{pH} 8$, buffer; the active fraction was identified in a cytotoxicity assay (see below).

The upper chamber of the ultrafiltration unit retained a cell-elongating activity (CEA) which was concentrated to one-tenth of the initial volume of culture filtrate. It was subsequently dialysed in the cold against PBS, pH 7.4 , or TE buffer (10 mM Tris- $\mathrm{HCl}, 1 \mathrm{mM}$ EDTA, pH 8) for 4 days to remove all residual CLT, and then further purified on a Sephadex G100 column with $50 \mathrm{~mm} \mathrm{NaCl}, 50 \mathrm{~mm}$ Tris-HCl, pH 8, buffer.

\section{Cytotoxicity assay}

McCoy cells were grown at $37^{\circ} \mathrm{C}$ in RPMI medium (Gibco) containing fetal calf serum 5\% and 24-well plates were seeded with $10^{4}$ cells $/$ well in $1 \mathrm{ml}$. Cells were allowed to attach, the medium was changed and $200 \mu \mathrm{l}, 50 \mu \mathrm{l}, 10 \mu \mathrm{l}$ or $2 \mu \mathrm{l}$ of toxin were added to each well $/ \mathrm{ml}$ of RPMI medium. Cells were incubated at $37^{\circ} \mathrm{C}$ and observed microscopically over $24 \mathrm{~h}$. Trypan blue was added to visualise dead cells and assist the estimation of the proportion of dead to control cells. For proliferation studies, $\left[{ }^{3} \mathrm{H}\right]$-thymidine or $\left[{ }^{14} \mathrm{C}\right]$-leucine was added either at the same time as the toxin (for CLT) or after a 24-h pre-incubation period with toxin (for CEA). Cells were harvested by trypsinisation after incubation for $2 \mathrm{~h}, 4 \mathrm{~h}$ or $24 \mathrm{~h}$ with the isotopes. Incorporation of radioactivity was measured in a scintillation counter.

\section{SDS-PAGE and Western blotting}

Samples of ultrafiltered and dialysed culture filtrates with CEA activity were precipitated with ice-cold trichloro-acetic acid to $10 \%$ and the precipitates were resuspended in $25 \mu \mathrm{l}$ of sample buffer (SDS 10\%, $20 \mathrm{mM}$ Tris- $\mathrm{HCl}, \mathrm{pH} 8.0,10 \mathrm{mM}$ DTT) and boiled for $3 \mathrm{~min}$ before loading on to SDS-PAGE $12 \%$ gels (FastGel system, BioRad) and electrophoresis.

Western blots were performed (MiniProtean II apparatus, BioRad) at $100 \mathrm{~V}$ for $1 \mathrm{~h}$ with $25 \mathrm{mM}$ Tris- $\mathrm{HCl}$, $\mathrm{pH} 8.3,130 \mathrm{~mm}$ glycine, SDS $1 \%$ in methanol $20 \%$ as the transfer buffer. Protein was transferred on to Hybond membrane (Amersham). The membrane was then incubated with skim milk powder $5 \%$ in TBS (25 mM Tris- $\mathrm{HCl}, \mathrm{pH} 8,130 \mathrm{mM} \mathrm{NaCl}, 2 \mathrm{mM} \mathrm{KCl}$ ) for $1-3 \mathrm{~h}$ at room temperature and subsequently with serum from a melioidosis patient ( 1 in 250 dilution) for $1 \mathrm{~h}$ at room temperature. Blots were developed with a 1 in 5000 dilution of peroxidase-conjugated anti-human IgG or IgM (Sigma) and the ECL detection system (Amersham).

\section{HPLC}

CLT was run on an RP-4 column (Waters) with a gradient of $0-20 \%$ methanol in water at a $1 \mathrm{ml} / \mathrm{min}$ flow rate for $15 \mathrm{~min}$.

\section{Results}

\section{Cytotoxicity of crude culture filtrates}

Crude culture filtrates of a selection of isolates from different sources and those concentrated 10-fold by ultrafiltration were tested for cytotoxicity against McCoy cells. Cytolethality was assessed microscopically by estimating the percentage of dead cells compared to control cells incubated with uninoculated Todd Hewitt broth. Surprisingly, the unconcentrated culture filtrates had a much stronger cytolethal effect (in terms of numbers of cells killed $/ \mathrm{ml}$ of filtrate) than the corresponding concentrated ones. Moreover, surviving cells were more elongated than control cells. This apparent anomaly could be explained if the culture filtrate contained two different activities, and the cytolethal activity, but not the cell-elongating activity, passed through the $10-\mathrm{kDa}$ cut-off membrane during concentration. This explanation was confirmed by the fact that the cytolethal activity of the crude culture filtrate was completely lost upon dialysis and the remaining activity was cell-elongating.

\section{Cytolethal toxin}

The active fraction of CLT recovered from the filtrate (the lower chamber) of the ultrafiltration unit and purified on a Sephadex G25 column had an apparent mol. wt of c. $3 \mathrm{kDa}$. Purified CLT lost $60 \%$ of its activity after overnight treatment with pronase at $37^{\circ} \mathrm{C}$ but only $10 \%$ of its activity after heat treatment at $100^{\circ} \mathrm{C}$ for $30 \mathrm{~min}$ (Table 1). However, in its crude state before column chromatography, CLT was protease resistant. On an RP-4 HPLC column the toxic activity was recovered from the fastest moving peak (Fig. 1); these observations are consistent with it being a peptide.

CLT caused cell death in vitro with effects becoming visible after incubation for $1 \mathrm{~h}$ and progressing over 8-12 h. Dead cells had a characteristic appearance: they were rounded, often surrounded by vesicles, some 
Table 1. CEA and CLT inactivation studies

\begin{tabular}{|c|c|c|}
\hline Toxin & Treatment ${ }^{*}$ & $\begin{array}{l}\text { Activity as } \\
\text { compared to } \\
\text { untreated control } \\
\text { preparation }(\%)\end{array}$ \\
\hline \multirow[t]{4}{*}{ CLT } & Untreated & 100 \\
\hline & Pronase $100 \mu \mathrm{g} / \mathrm{ml}$ at $37^{\circ} \mathrm{C}$ overnight & 40 \\
\hline & $30 \mathrm{~min}$ at $100^{\circ} \mathrm{C}$ & 90 \\
\hline & Pronase $100 \mu \mathrm{g} / \mathrm{ml}$ overnight at $37^{\circ} \mathrm{C}$ and $30 \mathrm{~min}$ at $100^{\circ} \mathrm{C}$ & 10 \\
\hline \multirow{4}{*}{ CEA factor } & Untreated & 100 \\
\hline & Pronase $100 \mu \mathrm{g} / \mathrm{ml}$ at $37^{\circ} \mathrm{C}$ overnight & 5 \\
\hline & $30 \mathrm{~min}$ at $100^{\circ} \mathrm{C}$ & $<10$ \\
\hline & Pronase $100 \mu \mathrm{g} / \mathrm{ml}$ at $37^{\circ} \mathrm{C}$ overnight and $30 \mathrm{~min}$ at $100^{\circ} \mathrm{C}$ & 5 \\
\hline
\end{tabular}

${ }^{*}$ All CLT treatment was performed in $50 \mathrm{mM} \mathrm{NaCl}, 20 \mathrm{mM}$ Tris-HCl buffer, pH 8; all CEA treatment was performed in PBS, $\mathrm{pH}$ 7.4.

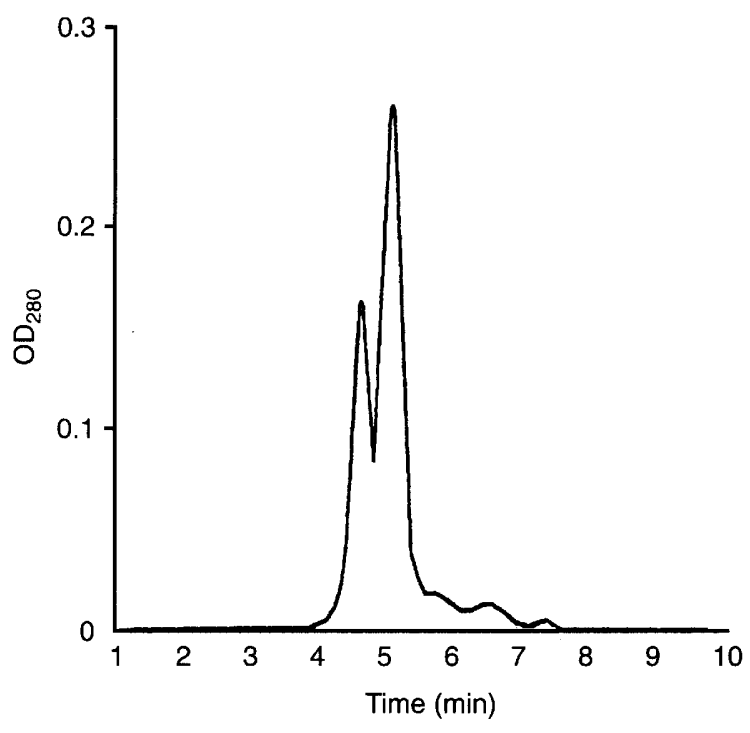

Fig. 1. HPLC of the CLT-containing fraction from a Sephadex G25 column. A semi-preparative Waters RP-4 column was used with a gradient of methanol $0-20 \%$ in water in $15 \mathrm{~min}$ with $1 \mathrm{ml} / \mathrm{min}$ flow. The first peak contains active CLT.

were inflated and the membrane always became distorted (Fig. 2b). CLT appeared to be either incorporated into cells or cell membranes or actively degraded as $\leqslant 10 \%$ of its activity was detectable after overnight incubation with cells. This was shown by transferring 'used' CLT-containing medium to healthy cells. The activity of pure CLT was stable for at least 3 days at $37^{\circ} \mathrm{C}$ and for at least 3 months at $4^{\circ} \mathrm{C}$.

The CLT of some isolates was active on $10^{4}$ cells with as little as $10 \mu \mathrm{l} / \mathrm{ml}$ of tissue culture medium (see below) and cellular DNA and protein synthesis (as assessed by ${ }^{3} \mathrm{H}$-thymidine and ${ }^{14} \mathrm{C}$-leucine incorporation) compared to healthy control cells were $90 \%$ inhibited after incubation for $1 \mathrm{~h}$ (Fig. 3).

\section{Cell-elongating activity}

The CEA was retained by the membrane and recovered from the upper chamber of the ultrafiltration unit. It could be separated completely from CLT by extensive
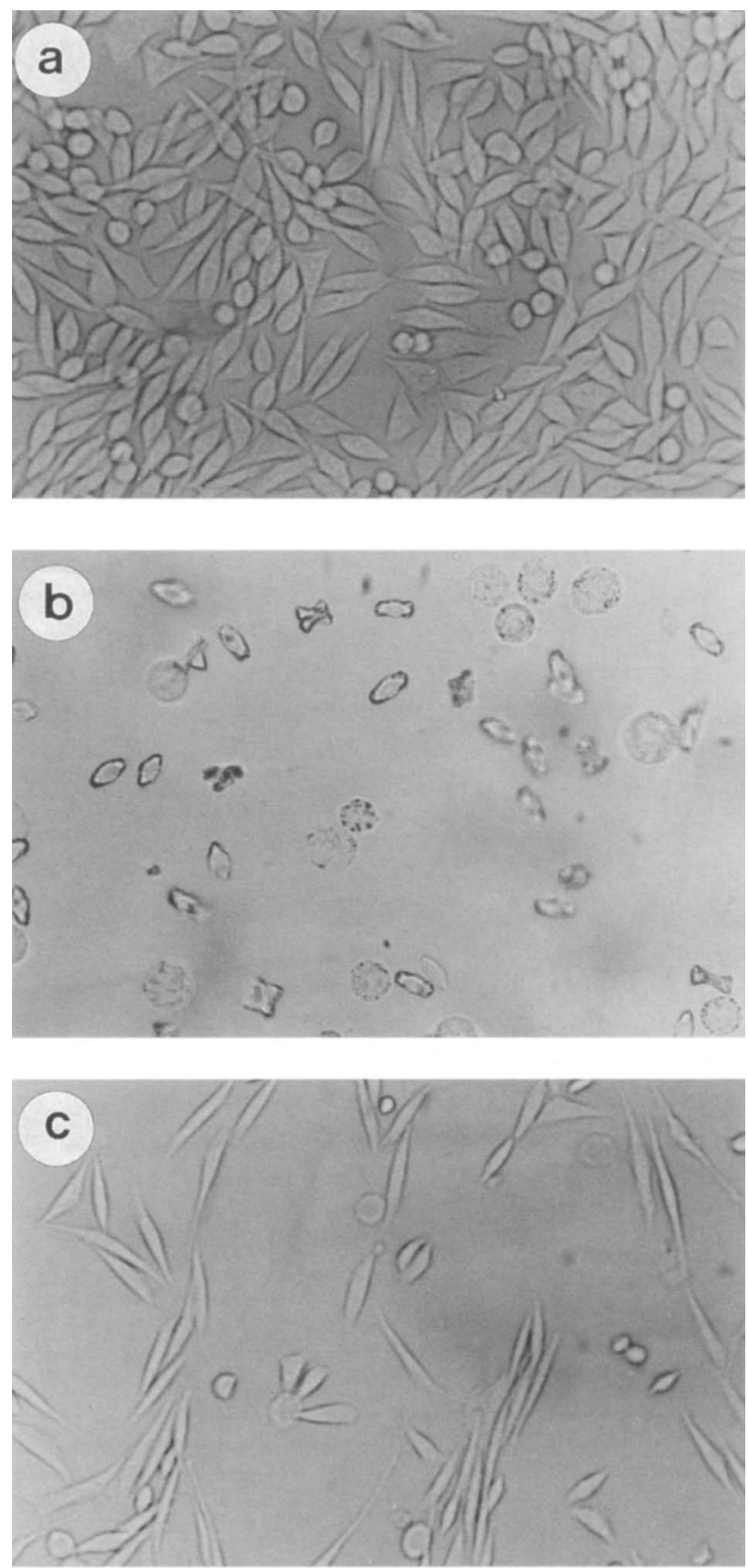

Fig. 2. Photomicrographs (250- and 500-fold magnification) of: a, healthy control McCoy cells; b, McCoy cells after overnight incubation with CLT; c, McCoy cells after incubation for $48 \mathrm{~h}$ with CEA factor. 
a
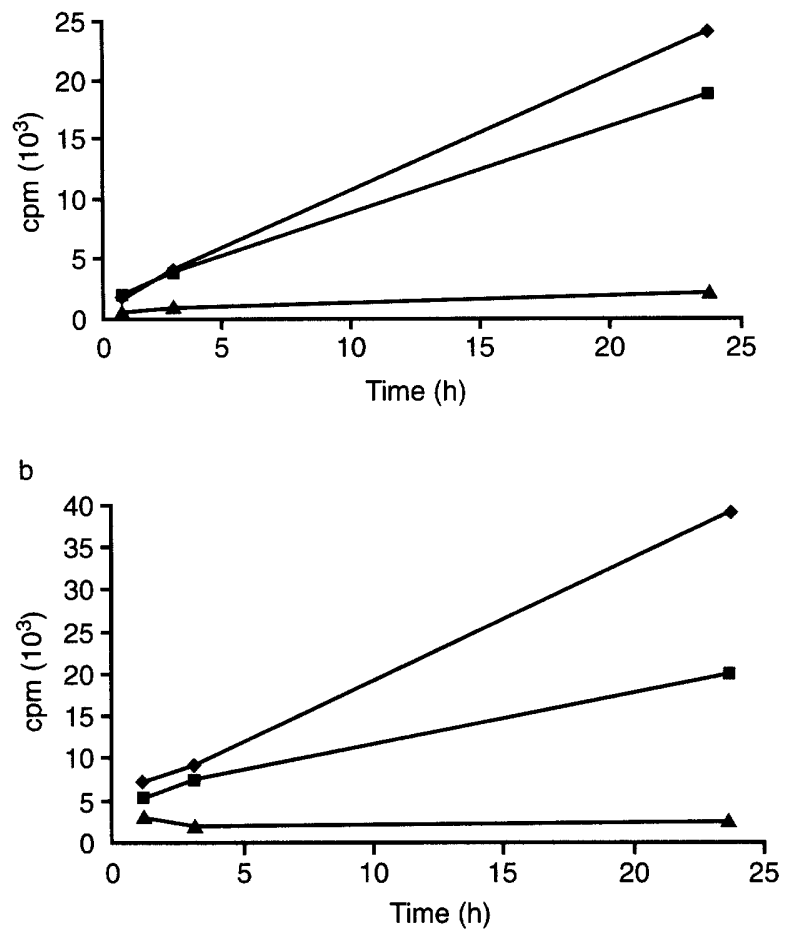

Fig. 3. Inhibition of: a, $\left[{ }^{14} \mathrm{C}\right]$-leucine; b, $\left[{ }^{3} \mathrm{H}\right]$-thymidine incorporation by CLT $(\boldsymbol{\Lambda})$; CEA $(\boldsymbol{\square})$ or control $(\bullet)$. For CLT, isotopes were added at the same time as the toxin; for CEA, cells were incubated overnight with the toxin before isotopes were added.

dialysis. Its effects of promoting cell elongation (Fig. 2c) and growth inhibition were observed only after incubation for $24-36 \mathrm{~h}$. After pre-incubation of cells with CEA for $16-20 \mathrm{~h}$ and subsequent overnight incubation with $\left[{ }^{3} \mathrm{H}\right]$-thymidine or $\left[{ }^{14} \mathrm{C}\right]$-leucine, respectively, DNA synthesis was inhibited by $50 \%$ and protein synthesis by $25 \%$ (Fig. 3). Growth inhibition and cell elongation were caused by very small amounts, (i.e., $<10 \mu$ ) of culture filtrate.

CEA is caused by a protein because it was heat labile and almost completely inactivated by pronase treatment (Table 1). A Western blot of crude culture filtrate

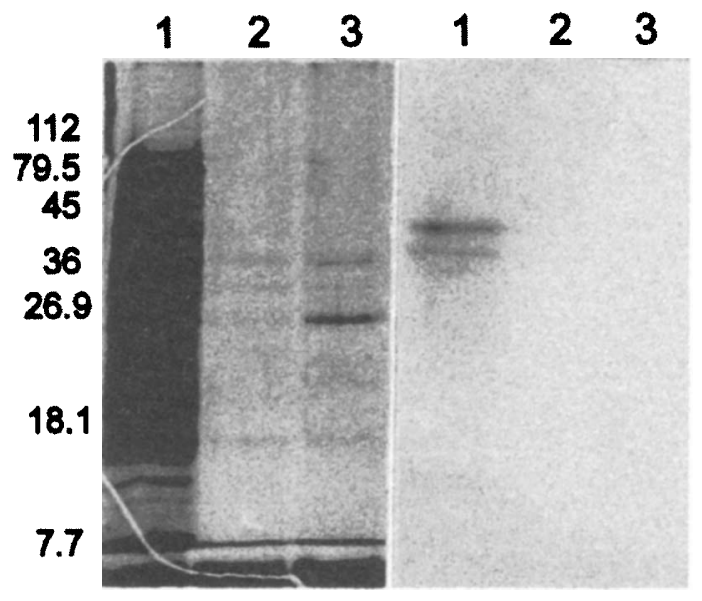

Fig. 4. Silver-stained SDS-PAGE (left panel) and Western blot (right panel) of size-fractionated and TCA-precipitated culture filtrate. Left hand side: the BioRad widerange mol.wt markers $(\mathrm{kDa})$. Lane 1 , content of upper chamber of the ultrafiltration unit containing the CEA; 2, $\mathbf{3}$, active fractions after Sephadex G100 column chromatography.

after ultrafiltration and dialysis, and probing with serum from a patient with chronic melioidosis, showed two major bands of $36 \mathrm{kDa}$ and $40 \mathrm{kDa}$ (Fig. 4) which were not prominent in a Coomassie-stained gel. After Sephadex G100 column chromatography, the CEA active fraction contained one prominent band of $24 \mathrm{kDa}$ and three minor bands of 34,27 and $16 \mathrm{kDa}$, none of which corresponded to the immunoreactive bands or gave a signal on the Western blot. This is consistent with the observation that the activity was not inhibited by antibodies in the serum of melioidosis patients. It is not clear if the fourpolypeptides are domains of one protein complex or simply co-purified proteins.

\section{Comparison between isolates from different sources}

The CLT activity of isolates from different sources (Table 2) such as patients with mild and severe disease,

Table 2. Differential toxicity of crude culture filtrates of isolate from different sources

\begin{tabular}{lll}
\hline $\begin{array}{l}\text { Isolate } \\
\text { no. }\end{array}$ & Source & $\begin{array}{l}\text { Cytolethal } \\
\text { activity }\end{array}$ \\
\hline 244 & Soil isolate from goat farm, causative strain of 1992-93 outbreak & Low \\
146 & Same strain as above, goat & Medium \\
186 & Same strain as above, isolate from goat that died & High \\
227 & Soil isolate & Low \\
231 & Soil isolate & Low \\
62 & Neurological patient & High \\
80 & Non-fatal melioid pneumonia patient & Low \\
60 & Non-fatal melioid pneumonia patient & High \\
303 & Neurological patient & High \\
338 & Mild melioid patient & Low \\
44 & Neurological patient & High \\
61 & Fatal melioid pneumonia patient & Medium \\
\hline
\end{tabular}

The classification of high, medium and low producers is based on quantification in which $100 \mathrm{U}=$ the amount of toxin that kills $100 \%$ of $10^{4}$ cells $/ \mathrm{ml}$ overnight at $37^{\circ} \mathrm{C}$ : low producers, $<2000 \mathrm{U} / \mathrm{ml}$, medium producers $2000-6000 \mathrm{U} / \mathrm{ml}$, high producers $>6000 \mathrm{U} / \mathrm{ml}$. 
like melioidosis encephalitis, and those from animals and soil was examined. Although great differences in the degree of growth inhibition or elongating activity of CEA were not found between isolates, marked differences were observed in CLT activity. This was quantified in arbitrary units with 1 unit representing the amount of toxin that killed $100 \mathrm{McCoy}$ cells in vitro. Thus, strains were divided into low $(<2000 \mathrm{U} /$ $\mathrm{ml})$, medium $(2000-6000 \mathrm{U} / \mathrm{ml})$ and high producers $(>6000 \mathrm{U} / \mathrm{ml})$. On this basis, soil isolates, typically with $1000 \mathrm{U} / \mathrm{ml}$, were usually the least toxic whereas isolates from patients with melioidosis encephalitis had the highest activity (up to $10000 \mathrm{U} / \mathrm{ml}$ ). Such differences were less pronounced when isolates were kept on plates for several months before culture in liquid media.

Interestingly, an isolate (186) from a goat was highly toxigenic, whereas a genetically identical (as determined by RAPD typing [14]) strain from soil (no. 244) from the corresponding goat farm was a low toxin producer. This suggests that CLT production is subject to regulation.

\section{Discussion}

Earlier reports, based on observations in an animal experiment, have described two different toxins in culture filtrates of $B$. pseudomallei $[9,10]$. Although a decrease in lethal activity after dialysis was observed, this was considered to be due to inactivation rather than loss of the toxin.

Recently an exotoxin was described that was isolated by Sephadex G100 gel filtration and subsequent dialysis [13]. The toxin inhibited DNA and protein synthesis only in relatively large amounts [12]. To detect a cytolethal effect, $20 \mu \mathrm{g}$ toxin $/ \mathrm{ml}$ were required, an amount equivalent to $50 \mathrm{ml}$ of bacterial culture. Therefore, it would be unlikely that this toxin could be the cause of the very rapid onset of septicaemic melioidosis. It is possible that the observed cytolethal effect in this report [12] was due to residual activity from CLT, most of which had been lost during dialysis. Because the assay systems differ between this study and those of other workers, the effects of the toxins described in the different studies may not be comparable, i.e., what is cytolethal in vitro may well be dermonecrotic in vivo.

It is possible that the CEA factor acts as a toxin, although at this stage there is no evidence for this. Cell-elongating toxins are common in enteropathogens. The group of 'cholera-like' toxins consist of one A polypeptide and five B polypeptides; they activate adenylate cyclase by NAD-linked ADP-ribosylation of the $\mathrm{G}_{\mathrm{s}}$ subunit of the adenylate cyclase complex, resulting in an increase of cAMP [15-18]. Vibrio hollisae produces a completely different cell-elongat- ing toxin which has no homology with 'cholera-like' toxins and acts through a cAMP-independent mechanism [19]. Aeromonas hydrophila and Campylobacter spp. also produce unrelated cell-elongating toxins that are all very slow acting [20].

Inhibition of DNA and protein synthesis has not been reported for these elongating toxins and it is not clear from the present study if such inhibition causes the observed cell elongation and growth inhibition or is a consequence of it. The effect described for other toxins is usually mediated by ADP-ribosylation of transcriptional factors as is seen with diphtheria toxin and Pseudomonas aeruginosa toxin [21-23]. However, these toxins eventually have a lethal effect and cell elongation has not been described as one of their effects.

CLT is fast acting, suggesting that it does not require interaction with intracellular components but may act directly on the membrane. Its effect is proportional to the ratio of toxin:cells and is not accumulative, indicating that the peptide may be incorporated or integrated into the cell membrane. Such mechanisms have been described for toxins of other organisms, e.g., the leucotoxin from Actinobacillus actinomycetemcomitans is a bacterial peptide toxin that forms pores in the membrane and causes death by colloid osmotic lysis through $\mathrm{Ca}^{2+}$ influx [24]. The Escherichia coli heat-stable toxin STB opens a GTP-binding regulatory, receptor operated $\mathrm{Ca}^{2+}$ channel and causes a rise in intracellular $\mathrm{Ca}^{2+}$ through influx from the outside [25].

The mechanisms of action of CLT and the CEA factor require further investigation and they may be different from those of other known toxins. At this stage it is unclear how their effects relate to the pathogenic processes of melioidosis.

Cytolethal activity varied by up to 10 -fold between isolates from different sources. Soil isolates were the least cytolethal and isolates from severely ill patients with melioidosis encephalitis were the most active.

The causative strain of a melioidosis outbreak on a goat farm near Darwin in 1992-1993 [14] showed almost 10 -fold differences in cytotoxic activity depending on whether the organism was isolated from soil or an animal, with differences still occurring between different animal isolates. The possibility of upregulation of virulence or toxicity during passage through animals has been discussed before [14]. The importance of regulation is also supported by the fact that isolates lost their cytotoxicity when maintained on plates for several months and were most active when grown freshly from a stock culture in glycerol broth.

Suggested reasons for the correlation of disease 
incidence with rainfall, and the wet season predominance of melioidosis remain to be confirmed [26]. The observation of differential toxicity suggests that toxin production may be induced when the organism is growing in the planctonic state, i.e., when liquid medium is added to soil for isolation of $B$. pseudomallei, or after heavy rainfalls. When the organism is in a dry state, toxin production may be suppressed. This would explain why infection does not occur during the dry season. However, there must be another mechanism of suppressing toxin expression, as the organism can survive within macrophages and remain latent for many years without causing symptoms [27].

The correlation of toxic activity with disease manifestation is not always straightforward, as the underlying condition of the patient is a major determinant of the severity of melioidosis. For example, one isolate with high toxic activity was from a patient with very severe illness but without risk factors, whereas a patient with chronic melioidosis but without severe symptoms was infected with a low-producer isolate. Interestingly, one isolate from a patient with non-fatal melioidosis was a high toxin producer in vitro.

Whether or not the condition of melioidosis encephalitis is due to very high toxin levels or a separate toxin is yet not clear. A distending toxin isolated from $E$. coli has been reported to have caused encephalitis [28].

CLT is a candidate for one of the factors involved in the rapid onset and dramatic course of septicaemic melioidosis. Therefore, it may be a possible target for intervention measures in seriously ill patients when antibiotics often fail. However, studies in vivo are required to establish the pathogenic role of this toxin.

This project was funded by a Howard Hughes Grant. We thank the Department of Primary Industry and Fisheries in Darwin for the animal isolates and Heidi Smith-Vaughan, Yvonne Wood and Maree Brennan for collecting and handling the clinical specimens.

\section{References}

1. Merianos A, Patel M, Lane JM et al. The 1990-1991 outbreak of melioidosis in the Northern Territory of Australia: epidemiology and environmental studies. Southeast Asian J Trop Med Public Health 1993; 24: 425-435.

2. Currie B, Howard D, Nguyen VT, Withnall K, Merianos A. The 1990-1991 outbreak of melioidosis in the Northern Territory of Australia: clinical aspects. Southeast Asian J Trop Med Public Health 1993; 24: 436-443.

3. Kanai K, Kondo E. Recent advances in biomedical sciences of Burkholderia pseudomallei (basonym: Pseudomonas pseudomallei). Jpn J Med Sci Biol 1994; 47: 1-45.

4. Chaowagul W, White NJ, Dance DAB et al. Melioidosis: a major cause of community-acquired septicemia in northern Thailand. J Infect Dis 1989; 159: 890-899.
5. Mays EE, Ricketts EA. Melioidosis: recrudescence associated with bronchogenic carcinoma twenty-six years following initial geographic exposure. Chest 1975; 68: 261-263.

6. Haase A, Melder A, Smith-Vaughan H, Kemp D, Currie B. RAPD analysis of isolates of Burkholderia pseudomallei from patients with recurrent melioidosis. Epidemiol Infect 1995; 115: $115-121$.

7. Chaowagul W, Supputtamongkol Y, Dance DA, Rajchanuvong A, Pattara-arechachai J, White NJ. Relapse in melioidosis: incidence and risk factors. $J$ Infect Dis 1993; 168: $1181-1185$

8. Woods ML, Currie BJ, Howard DM et al. Neurological melioidosis: seven cases from the Northern Territory of Australia. Clin Infect Dis 1992; 15: 163-169.

9. Heckly RJ, Nigg C. Toxins of Pseudomonas pseudomallei II. Characterization. J Bacteriol 1958; 76: 427-436.

10. Heckly RJ. Differentiation of exotoxin and other biologically active substances in Pseudomonas pseudomallei filtrates. J Bacteriol 1964; 88: 1730-1736.

11. Sexton MM, Jones AL, Chaowagul W, Woods DE. Purification and characterization of a protease from Pseudomonas pseudomallei. Can J Microbiol 1994; 40: 903-910.

12. Mohamed R, Nathan S, Embi N, Razak N, Ismail G. Inhibition of macromolecular synthesis in cultured macrophages by Pseudomonas pseudomallei exotoxin. Microbiol Immunol 1989; 33: 811-820.

13. Ismail G, Noor Embi N, Omar O, Allen JC, Smith CJ. A competitive immunosorbent assay for detection of Pseudomonas pseudomallei exotoxin. J Med Microbiol 1987; 23: 353-357.

14. Haase A, Smith-Vaughan H, Melder A et al. Subdivision of Burkholderia pseudomallei into multiple types by random amplified polymorphic DNA analysis provides new insights into epidemiology. J Clin Microbiol 1995; 33: 1687-1690.

15. Scott DA, Kaper JB. Cloning and sequencing of the genes encoding Escherichia coli cytolethal distending toxin. Infect Immun 1994; 62: 244-251.

16. Okuda J, Kurazono H, Takeda Y. Distribution of the cytolethal distending toxin A gene $(c d t \mathrm{~A})$ among species of Shigella and Vibrio, and cloning and sequencing of the $c d t$ gene from Shigella dysenteriae. Microb Pathog 1995; 18: 167-172.

17. Pickett CL, Cottle DL, Pesci EC, Bikah G. Cloning, sequencing, and expression of the Escherichia coli cytolethal distending toxin genes. Infect Immun 1994; 62: 1046-1051.

18. Bag PK, Ramamurthy T, Nair UB. Evidence for the presence of a receptor for the cytolethal distending toxin (CLDT) of Camplyobacter jejuni on CHO and HeLa cell membranes and development of a receptor-based enzyme-linked immunosorbent assay for detection of CLDT. FEMS Microbiol Lett 1993; 114: $285-291$.

19. Kothary MH, Claverie EF, Miliotis MD, Madden JM, Richardson SH. Purification and characterization of a Chinese hamster ovary cell elongation factor of Vibrio hollisae. Infect Immun 1995; 63: 2418-2423.

20. Johnson WM, Lior H. A new heat-labile cytolethal distending toxin (CLDT) produced by Campylobacter spp. Microb Pathog $1988 ; 4: 115-126$

21. Middlebrook JL, Dorland RB. Response of cultured mammalian cells to the exotoxins of Pseudomonas aeruginosa and Corynebacterium diphtheriae: differential cytotoxicity. Can J Microbiol 1977; 23: 183-189.

22. Gray GL, Smith DH, Baldridge JS et al. Cloning, nucleotide sequence, and expression in Escherichia coli of the exotoxin A structural gene of Pseudomonas aeruginosa. Proc Natl Acad Sci USA 1984; 81: 2645-2649.

23. Blanke SR, Huang K, Wilson BA, Papini E, Covacci A, Collier RJ. Active-site mutations of the diphtheria toxin catalytic domain: role of histidine- 21 in nicotinamide adenine dinucleotide binding and ADP-ribosylation of elongation factor 2. Biochemistry 1994; 33: 5155-5161.

24. Taichman NS, Iwase M, Lally ET, Shattil SJ, Cunningham ME, Korchak HM. Early changes in cytosolic calcium and membrane potential induced by Actinobacillus actinomycetem comitans leukotoxin in susceptible and resistant target cells. $J$ Immunol 1991; 147: 3587-3594.

25. Dreyfus LA, Harville B, Howard DE, Shaban R, Beatty DM, Morris SJ. Calcium influx mediated by the Escherichia coli heat-stable enterotoxin B (STB). Proc Natl Acad Sci USA 1993; 90: 3202-3206. 
26. Thomas AD, Forbes-Faulkner J, Parker M. Isolation of Pseudomonas pseudomallei from clay layers at definite depths. Am J Epidemiol 1979; 110: 515-521.

27. Jones $\mathrm{AL}$, Beveridge TJ, Woods DE. Intracellular survival of Burkholderia pseudomallei. Infect Immun 1996; 64: 782-790.
28. Anderson JD, MacNab AJ, Gransden WR, Damm SM, Johnson WM, Lior H. Gastroenteritis and encephalopathy associated with a strain of Escherichia coli O55 K59:H4 that produced a cytolethal distending toxin. Pediatr Infect Dis $J$ 1987; 6: 1135-1136. 